\title{
An Assessment \\ Of A Practical Experience Requirement For Undergraduate Business Majors
}

Doyle A. Eiler, University of Mary Hardin-Baylor

Paul A. Stock, University of Mary Hardin-Baylor

\begin{abstract}
Approximately five years ago, the University of Mary Hardin-Baylor added a unique, practical work experience requirement to the customary graduation requirements for an undergraduate business degree. This paper examines the perceived value of this requirement from the perspective of the students (now alumni) who have been subject to the requirement and the fulltime faculty who advise undergraduates. $90 \%$ of the responding alumni believe that this practical requirement is a good idea, has been valuable to them and should be enhanced and continued.
\end{abstract}

\section{INTRODUCTION}

$\mathscr{I}$ n 2002, the College of Business (CoB) at the University of Mary Hardin-Baylor (UMHB) in Belton, Texas adopted a unique, additional requirement for graduation. All undergraduate students with a business major were required to acquire at least 300 hours of practical work experience that was closely related to their academic field of study prior to graduation. The practical experience could be obtained through fulltime employment, part-time employment, an internship, an apprenticeship, international experience, co-op, or student teaching.

Since none of the 31 AACSB accredited Colleges of Business in the state of Texas have a similar requirement, the perceived usefulness and value of this unique practical experience requirement deserves study. To explore this requirement, two separate (but related) surveys were conducted. One survey was conducted among UMHB alumni who have been subjected to the requirement and the other was conducted among full-time faculty of the $\mathrm{CoB}$ who teach and advise undergraduate students.

A web-based survey tool was used to administer each survey. An e-mail was sent explaining the purpose of the study and asking them (alumni and faculty separately) to click on a link that would take them to the appropriate on-line survey. The e-mail addresses for the alumni were obtained from the UMHB Alumni office. Each survey took approximately 5 to 10 minutes to complete. A copy of the alumni survey is at Appendix A and a copy of the faculty survey is at Appendix B.

\section{ALUMNI RESULTS}

A total of 369 valid e-mail addresses for university alumni from 2002 through 2007 were received from the university's Alumni Office. A total of 83 alumni responded to the survey, which represents a response rate of over 22 percent. The breakdown of the response rate by class year is shown below in Table 1 . 
Table 1

Response Rates for Alumni

\begin{tabular}{|c|c|c|c|}
\hline Class Year & Valid E-mail & Responses & Rate \\
\hline 2002 & 52 & 6 & $12 \%$ \\
\hline 2003 & 74 & 18 & $24 \%$ \\
\hline 2004 & 66 & 18 & $27 \%$ \\
\hline 2005 & 45 & 8 & $22 \%$ \\
\hline 2006 & 73 & 16 & $29 \%$ \\
\hline 2007 & 59 & 17 & $22 \%$ \\
\hline Total & 369 & 83 & \\
\hline
\end{tabular}

The survey asked how the requirement for practical experience was viewed when the alumni was a student. The results are shown below in Table 2:

Table 2

Alumni View of Requirement as a Student

\begin{tabular}{|c|c|}
\hline Alumni View when a Student & Percent of Response \\
\hline Absolutely Necessary & $20 \%$ \\
\hline Useful and Meaningful & $44 \%$ \\
\hline Burdensome and Difficult & $18 \%$ \\
\hline Changed View from Negative to Positive & $17 \%$ \\
\hline Unnecessary & $1 \%$ \\
\hline
\end{tabular}

Over $60 \%$ of the alumni felt the practical experience helped them in their job search after graduation. The (open-ended) reasons for how the 300 hours of practical work experience helped them in their job search are shown below in Table 3 below.

Table 3

Requirement Helped in Job Search

\begin{tabular}{|c|c|}
\hline Helped in Job Search & Percent of Response \\
\hline Distinguished Me from Other Applicants & $50 \%$ \\
\hline Improved my Resume & $35 \%$ \\
\hline Improved my Skills & $12 \%$ \\
\hline Improved my Confidence & $3 \%$ \\
\hline
\end{tabular}

Some alumni explained that the experience allowed them to identify their own strengths and weaknesses in the workplace. Other alumni said the practical experience allowed them to discover their own interests in their academic field. In fact, one respondent said the practical experience made him realize he didn't like his field of study, so he changed his academic major. Four alumni said they were hired full-time after graduation by the business that gave them the practical experience. Only one respondent said the practical experience did not help them in their job search.

$52 \%$ of the alumni said the required work experience helped them perform better at their first job. The most frequently mentioned (open-end) areas identified included:

- $\quad$ Helped me to deal with co-workers

- $\quad$ Made me pay more attention to details

- Taught me about workplace etiquette 
- Taught me about customer service

- $\quad$ Gave me self-confidence

- $\quad$ Taught me about time management

- Taught me how to take constructive criticism

To capture the alumni's overall perspective on the 300 hour practical experience requirement, they were asked what they thought of the requirement. $90 \%$ of the surveyed alumni thought the requirement was a good idea and should be continued. The most common (open-end) reasons given for their support of the requirement were:

- $\quad$ Students can't learn everything they need to know in a classroom

- $\quad$ Experience gives UMHB graduates an advantage over other college graduates

- Gives the students the skills they need to be successful after graduation

- $\quad$ Forces students to gain work experience they won't obtain on their own initiative

- Helps students learn about their chosen field of academic study

While there was clearly strong support for the continuation of the practical experience requirement, $40 \%$ of the alumni felt that some modification to the requirement or its administration would make it more valuable. The most frequently mentioned modifications suggested were:

- $\quad$ Provide more assistance to the students to locate a job, internship, co-op, etc.

- $\quad$ Establish more business partners who are willing to provide the experience to students and have preapproved positions

- Allow any relevant experience received before transferring to the university to count towards this requirement

- $\quad$ Ensure all undergraduate students with a business-related major be informed of this requirement during their first semester of classes

- $\quad$ Reduce the number of hours required

\section{FACULTY RESULTS}

The 12 full-time faculty in the CoB who provide most of undergraduate teaching and advising completed the faculty survey. They were asked to explain (open-end) their understanding of why the CoB had the 300 hours of practical experience requirement. The most common responses were:

- $\quad$ To ensure students can apply classroom lessons to real world situations

- $\quad$ To give students insight into what their academic profession involves

- $\quad$ Employers want college graduates to have practical experience

- $\quad$ To help the students network for future employment

- $\quad$ To differentiate our graduates from other colleges and universities

- $\quad$ To enhance the appeal of our graduates to future employers

The faculty was asked how they thought most students find a qualifying practical work experience. The faculty estimated that $83 \%$ students found their experience opportunity through their own initiative. $17 \%$ were estimated to have used a faculty referral.

In terms of the estimated difficulty in finding a qualifying experience, the faculty felt that only about $1 / 4$ of the students had a somewhat or very difficult time. The results are shown below in Table 4 below. 
Table 4

Level of Difficulty to Find a Position

\begin{tabular}{|c|c|}
\hline Level of Difficulty & Est. Pct of Students \\
\hline Very Easy & $20 \%$ \\
\hline Somewhat Easy & $27 \%$ \\
\hline Average & $28 \%$ \\
\hline Somewhat Difficult & $20 \%$ \\
\hline Very Difficult & $7 \%$ \\
\hline
\end{tabular}

An important question with respect to any experience requirement is the "quality" of the experience relative to the objective of providing a relevant and meaningful learning opportunity. While the CoB has identified specific types of experiences that are considered appropriate, individual students may not always be able to find a fully satisfying opportunity. The faculty was asked how they would describe the "quality" of the practical work experience that the students were receiving. The results of this question are shown below in Table 5.

Table 5

Level of Quality of Actual Positions

\begin{tabular}{|c|c|}
\hline Level of Quality & Est. Pct of Students \\
\hline Challenging & $29 \%$ \\
\hline Above Average & $24 \%$ \\
\hline Adequate & $23 \%$ \\
\hline Marginal & $14 \%$ \\
\hline Barely Meets Requirement & $6 \%$ \\
\hline Doesn't Meet Requirement & $4 \%$ \\
\hline
\end{tabular}

When asked if they thought the 300 hours of practical experience gave our graduates a meaningful advantage over other colleges and universities in obtaining employment, $75 \%$ of the faculty agreed. The most common reasons are shown below:

- $\quad$ Being able to show the successful application of classroom knowledge in a real business environment

- $\quad$ Experience proves to potential employers that the graduate can perform in their field and has the necessary skills to be successful

- $\quad$ Provides our graduates with contacts and good references in their field

- $\quad$ Employers often think recent college graduates are book-smart but lack practical experience

- Improves the student's confidence that they can perform in their academic field of study

Finally, the faculty was asked if they thought the requirement for 300 hours of practical experience should be continued as is, modified in some way, or terminated. Two thirds of the faculty said the requirement should continue as is without any change. One third of the faculty thought the requirement should be continued, but modified in some way. The most common modifications recommended were as follows:

- A faculty mentor should be assigned to each student to assist the student in locating a qualifying position, co-op, or an internship.

- The 300 hours of practical experience should count towards 3 or 6 credits of coursework to reduce the cost, time, and effort of an undergraduate degree. Maybe the 300 hours could substitute for another course or two that is required now. 


\section{CONCLUSIONS}

With $90 \%$ of the surveyed alumni believing the requirement for practical experience is a good idea, the value of this unique graduation requirement is validated by its target "customers". This practical experience helped them get their first job (60\%) by distinguishing them from other applicants.

$52 \%$ of the alumni said the required practical experience helped them perform better during their first job after graduation. Most of the alumni said the work experience helped them to deal with co-workers better and pay more attention to detail during their first job, skills that will be beneficial throughout their careers.

Like many other graduation requirements, the perceived value of the practical experience requirement changed over time for many of the students. While $44 \%$ of the alumni felt the requirement was useful and meaningful when they were students, another $17 \%$ admitted to changing their opinion about the requirement from a negative view to a positive one while they were undergraduate students.

From the faculty perspective, $75 \%$ said the requirement for 300 hours of practical experience gave our graduates a meaningful advantage over the graduates from other colleges and universities. The most common reasons given for this advantage include the application of classroom knowledge in a real business environment and the ability to perform successfully in their academic field.

\section{RECOMMENDATIONS}

While there is clearly strong support from both the university alumni and the faculty to continue the practical work experience requirement as a part of the CoB's graduation requirements, significant portions of both the alumni (40\%) and the faculty (33\%) feel that some modifications to the requirement or improvements to how it is administered could make it even more valuable.

The alumni would like to see more assistance given to the students in helping them locate a qualifying position. They suggested the College of Business establish more partnerships with local businesses to develop a list of "pre-approved" positions. One suggestion from the faculty was to assign a faculty "mentor" for each student early in their academic experience at the university to assist the student in finding a qualifying position.

The alumni also emphasized how important it is to inform all undergraduate and transfer students in the College of Business about this requirement as early in their academic program as possible. The College of Business may want to determine the specifics (when, where, and how) about the best time to inform new students about this requirement so they can plan their activities.

Several of the alumni said they had years of work experience in their academic field of study before attending the university. However, this work experience did not count toward the 300 hours required for graduation. The College of Business should consider whether prior work experience should count if the student can obtain necessary written evidence that it does relate to their academic major.

Several of the alumni suggested the number of hours should be reduced and one former student said the number of hours should be increased. The College of Business should reevaluate if 300 hours is the appropriate amount of time for this requirement.

Finally, some of the faculty raised questions as to types of experience being counted as "qualifying" while others suggested the possible consideration of counting the 300 hours of practical experience toward actual coursework in a student's degree plan.

All of the recommendations mentioned above are an attempt to improve a graduation requirement that clearly has the overwhelming support of both alumni and faculty. We believe the College of Business should examine, discuss, and evaluate each of these recommended modifications to the current requirement to determine their feasibility and usefulness. 


\section{ABOUT THE AUTHORS}

Paul A. Stock is an Assistant Professor of Economics at the University of Mary Hardin-Baylor in Belton, Texas. He received his B.S. in Business Administration from Clarion University of Pennsylvania in 1982, M.B.A. from Oklahoma City University in 1989, and Ph.D. in Economic Education from Ohio University in 1995. Dr. Stock teaches and conducts research in macroeconomics and economic education.

Doyle A. Eiler is an Associate Professor of Management and Marketing at the University of Mary Hardin-Baylor in Belton, Texas. He earned his B.S. in Agricultural Economics from Purdue University, and the Ph.D. in Marketing from Oregon State University. His primary interest is undergraduate education.

\section{REFERENCES}

1. 2006-2007 Undergraduate Catalog, University of Mary Hardin-Baylor, Belton, TX

Appendix A

Alumni Survey 2007

Introduction: This survey is being distributed to recent graduates of UMHB's College of Business as part of the College's ongoing review of graduation requirements.

We want to be sure to include your perspective, so please take the five minutes needed to complete this short survey.

Beginning in 2002, the College of Business initiated a unique, additional graduation requirement.

"All students majoring under any degree program of the College of Business are required to acquire three hundred hours of practical work experience while enrolled at UMHB."

"Practical work experience must be in the area of the student's anticipated major and may be acquired through fulltime employment, part-time employment, internships, apprenticeships, international experiences or student teaching." (2006-2007 Undergraduate Catalog, p95)

1. How did you feel about the College's 300 hour practical experience requirement when you were a student at UMHB?

2. Has your perspective changed since you were a student? If so, how?

3. Do you feel that the 300 hours of practical experience helped you in your job search? （Yes or No ) Why or why not?

4. Do you feel that the 300 hours of practical experience helped you perform better in your first job after college? Why or why not?

5. Do you think the 300 hours of practical work experience is a good idea or not? Please share with us the reason(s) for your choice.

6. Do you think the 300 hours of practical work experience requirement should be continued as is, modified or eliminated all together?

7. If you chose to Modify, how would you modify it? If you chose to eliminate it, why would you recommend elimination?

8. What was your academic major at UMHB?

9. What year did you graduated?

10. Number of different employers you have had since graduation? 


\section{Appendix B}

Faculty Survey 2007

Introduction: This survey is being distributed to UMHB College of Business faculty. It is a companion to the survey being distributed to current students and recent graduates of UMHB's College of Business as part of the College's ongoing review of its graduation requirements.

We want to be sure to include your perspective, so please take the few minutes needed to complete this short survey.

Beginning in 2002, the College of Business initiated a unique, additional graduation requirement.

"All students majoring under any degree program of the College of Business are required to acquire three hundred hours of practical work experience while enrolled at UMHB."

"Practical work experience must be in the area of the student's anticipated major and may be acquired through fulltime employment, part-time employment, internships, apprenticeships, international experiences or student teaching." (2006-2007 Undergraduate Catalog, p95)

1. What is your current understanding of why the College has a 300 hour practical experience requirement?

2. How do you think most students find their jobs, internships, etc. to fill the 300 hour requirement?
a. Career Services
b. Faculty referral
c. Through a friend or family member
d. Advertisement
e. Own initiative
f. Other (please specify)

3. How easy or difficult is it for students to find a qualifying job or internship? (provide a percentage for each category below to total 100 percent)
a. Very easy
b. Somewhat easy
c. Average
d. Somewhat difficult
e. Very difficult

4. How would you describe the general "quality" of the work experience of your students. (provide a percentage for each category below to total 100 percent)
a. Generally challenging \& fully meets the requirement
b. Generally OK \& clearly meets the requirement
c. Generally adequate to meet the requirement
d. Generally marginal to meet the requirement
e. Barely meets the requirement
f. Experience (though counted) doesn't meet the requirement

5. Have you had students who had significant difficulty in meeting the $\mathbf{3 0 0}$ requirement? If yes, please describe the difficulty (ies).

6. Do you feel that the 300 hours of practical experience give UMHB graduates a meaningful advantage in getting a job? Why or why not?

7. Do think the current 300 hour requirement should be changed, modified or even terminated? Why or why not? 
NOTES 